\title{
Pendekatan Interpretasi Teologis Kitab Suci dan Prasuposisi-Prasuposisi Teologis di Baliknya
}

\author{
Theological Interpretation of the Scripture \\ and Theological Presuppositions Behind It
}

\author{
Carmia Margaret \\ Rohaniwan Gereja Kristen Immanuel (GKIm) Hosanna Bandung \\ Korespondensi: carmia.margaret95@gmail.com
}

\begin{abstract}
Abstrak: Cukup banyak tokoh dan tulisan yang berupaya memperkenalkan, mendiskusikan, dan menunjukkan cara kerja pendekatan Interpretasi Teologis Kitab Suci atau yang lebih dikenal sebagai Theological Interpretation of Scripture (TIS), tetapi tidak banyak yang sebenarnya mendedah pemikiran-pemikiran teologis-filosofis di baliknya. Tulisan ini akan memperkenalkan natur, esensi, dan karakteristik khas pendekatan TIS melalui beberapa kepercayaan teologis dasar yang membentuk dan melatarbelakanginya. Kepercayaan-kepercayaan dasar ini dapat diibaratkan sebagai "DNA" bagi pendekatan TIS dan sekaligus membedakannya dari pendekatan-pendekatan tafsir lainnya. Pendekatan TIS agaknya paling baik dipahami sebagai pembacaan yang dilakukan di dalam dua konteks, yaitu konteks teologis dan eklesial. Dalam konteks teologis, pendekatan TIS memandang Kitab Suci sebagai tulisan yang bersifat sakral, Kitab Suci adalah medium komunikasi Ilahi kepada umat di sepanjang sejarah bahkan hingga hari ini, Kitab Suci memiliki kesatuan dalam seluruh bagiannya dengan Yesus Kristus sebagai pusat dan pengikat, dan Kitab Suci paling baik dibaca dengan kesadaran akan lensa teologis pembacanya. Dalam konteks eklesial, pendekatan TIS menekankan keimaman rajani seluruh anggota tubuh Kristus sebagai pembaca teks, keniscayaan komunitas di dalam pembacaan, dan fungsi normatif teks yang bertujuan menghasilkan transformasi dalam kehidupan umat.
\end{abstract}

Kata-kata kunci: Interpretasi Teologis Kitab Suci; Pembacaan Teologis, Pembacaan Eklesial

Abstract: There are plenty of figures and writings that attempt to introduce, discuss, and show the workings of Theological Interpretation of Scripture (TIS) as an approach in reading the Holy Scripture; however, not many that actually dissect the theological-philosophical thoughts laid behind it. This paper will discuss the nature, essence, and characteristics of the TIS approach through some of the forming convictions behind it, which can be said as "DNA" for the TIS approach and at the same time, differentiates it from other interpretive approaches. The TIS approach seems best understood as a reading that happened in two contexts, namely theological and ecclesial contexts. In a theological context, the TIS approach believes that the Scripture is a sacred writing, the Scripture is a medium of divine communication to people throughout history even today, the Scripture has a unity in all its parts with Jesus Christ as the center and binding, and the Scripture is best read with an awareness of theological lenses of the reader. In an ecclesial context, the TIS approach emphasizes the royal priesthood of all members of the body of Christ as readers of the text, the necessity of the community of believers in reading, and the normative function of the text aimed at producing transformation in the lives of the people of God.

Keywords: Theological Interpretation of Scripture, Theological Reading, Ecclesial Reading 


\section{PENDAHULUAN: BERKENALAN DENGAN PENDEKATAN TIS}

Pendekatan Interpretasi Teologis Kitab Suci atau Theological Interpretation of Scripture (selanjutnya disingkat TIS) sedang mendapatkan lampu sorot dari berbagai kalangan teolog dan sarjana biblika sejak sekitar awal 1990an. ${ }^{1}$ Minat besar pada subjek ini terlihat dari banyaknya publikasi yang muncul, mulai dari proyek, ${ }^{2}$ monograf, buku, jurnal, ${ }^{3}$ kamus, ${ }^{4}$ serta tafsiran $^{5}$ yang berupaya memperkenalkan

${ }^{1}$ Stanley E. Porter, "What Exactly is Theological Interpretation of Scripture, and is It Hermeneutically Robust Enough for the Task to Which It Has Been Appointed?," dalam Horizons in Hermeneutics: A Festschrift in Honor of Anthony C. Thiselton, ed. Stanley E. Porter dan Matthew R. Malcolm (Grand Rapids: Eerdmans, 2013), 234. Ketertarikan terhadap pendekatan TIS tidak dapat dilepaskan dari gelombang ressourcement yang sekarang ini marak diminati oleh para teolog Protestan (lih. mis. W. David Buschart dan Kent D. Eilers, Theology as Retrieval: Receiving the Past, Renewing the Church [Downers Grove: Intervarsity, 2015]).

${ }^{2}$ Misalnya "The Scripture Project," sebuah proyek kerja kolektif yang dilakukan oleh 15 orang pendeta dan sarjana dalam ilmu studi biblika dan teologi, yang dibentuk oleh Center of Theological Inquiry (Princenton, New Jersey). Kelompok ini bertemu secara berkala selama 4 tahun (1998-2002) dan mempunyai misi untuk mengatasi fragmentasi disiplin teologi mereka masing-masing dengan cara membaca Kitab Suci bersama-sama dan memikirkan bagaimana pembacaan Kitab Suci sebaiknya dilakukan dalam konteks edifikasi umat Allah. Hasil dari proyek kolektif ini adalah sebuah buku yang sering menjadi acuan bagi diskusi interpretasi teologis Kitab Suci, yaitu Ellen F. Davis dan Richard B. Hays, ed., The Art of Reading Scripture (Grand Rapids: Eerdmans, 2003).

${ }^{3}$ Seri jurnal yang khusus membahas mengenai pendekatan ini misalnya Journal of Theological Interpretation yang diterbitkan dua kali setahun oleh penerbit Eisenbrauns sejak 2007.

${ }^{4}$ Mis. Kevin J. Vanhoozer, ed., Dictionary for the Theological Interpretation of the Bible (Grand Rapids: Baker Academic, 2005). Selanjutnya disingkat DTIB.

${ }^{5} \mathrm{Hal}$ ini dapat dilihat dari masifnya penerbitan dari berbagai seri dalam kurun waktu yang berdekatan, misalnya seri Brazos Theological Commentary on the Bible (BTCB) yang volume pertamanya, tafsiran Kisah Para Rasul dari Jaroslav Pelikan, terbit tahun 2005, kini sudah menerbitkan 20 volume dan sedang menyiapkan 25 volume lain yang masih dalam proses penulisan. Selain itu, ada pula Two Horizons Commentary (THC) yang terbitan perdananya, tafsiran Filipi dari Stephen E. Fowl, juga terbit tahun 2005, dan sekarang sudah menerbitkan 19 judul lainnya. Seiring dengan itu, banyak pula artikel yang mengulas bentuk-bentuk dan cara kerja tafsiran teologis untuk pendekatan ini beserta contoh penerapannya, sekaligus tulisan-tulisan lain yang berusaha membedah dan mengkritisinya. ${ }^{6}$ Oleh pendukungnya, TIS digadang-gadang sebagai sebentuk pendekatan penafsiran baru yang dapat menjadi jawaban bagi kebuntuan penafsiran masa kini khususnya dalam hal korelasi fungsi deskriptif dan fungsi normatif teks. Di sisi lain, orang-orang yang menolak TIS cenderung beranggapan bahwa pendekatan ini "salah alamat" karena masalah yang hendak dijawab itu hanya sebuah utopia.

Sayangnya, hampir seluruh diskusi ini hanya direkam di dalam tulisan-tulisan berbahasa asing, dan sedikit sekali, atau bahkan hampir tidak ada, tokoh dan tulisan yang memaparkannya dalam konteks dan bahasa Indonesia. Sejauh ini, agaknya hanya Hendry Ongkowidjojo yang telah menerbitkan tulisan pengantar kepada pendekatan TIS di dalam bahasa Indonesia. ${ }^{7}$ Ia memaparkan tujuh

menemukan kesamaan, perbedaan, dan keistimewaannya dari tafsiran-tafsiran lain yang sudah terlebih dahulu beredar dan digunakan (lih. mis. C. Kavin Rowe dan Richard B. Hays, "What is a Theological Commentary?: A Book Symposium on Jaroslav Pelikan, Acts, Brazos Theological Commentary on the Bible [Grand Rapids: Brazos, 2005]," Pro Ecclesia 16, no. 1 [2007]: 26-32; Michael Pasquarello III, "Back to the Future: The Promise of Recent Theological Commentary," JTI 3, no. 2 [2009]: 307-315; Seth Haringer, "The Practice of Theological Commentary," JTI 4, no. 1 [2010]: 127-138; Tim Meadowcroft, "Theological Commentary: A Diversifying Enterprise," JTI 7, no. 1 [2013]: 133-151; Mark Gignilliat dan Jonathan T. Pennington, "Theological Commentary," dalam A Manifesto for Theological Interpretation, ed. Craig G. Bartholomew dan Heath A. Thomas [Grand Rapids: Baker Academic, 2016], 237-256; Kevin J. Vanhoozer, "Theological Commentary and 'the Voice from Heaven': Exegesis, Ontology, and the Travail of Biblical Interpretation," 1-38 dalam On the Writing on the New Testament Commentary: Festschrift for Grant R. Osborne on the Occasion of His $70^{\text {th }}$ Birthday, ed. Stanley E. Porter dan Eckhard J. Schnabel [Leiden: Brill, 2012], 267-298).

${ }^{6}$ Lih. mis. D.A. Carson, "Theological Interpretation of Scripture: Yes... But...," dalam Theological Commentary: Evangelical Perspectives, ed. R. Michael Allen (London: T\&T Clark, 2011), 187-207; R.W.L. Moberly, "What is Theological Interpretation of Scripture?," JTI 3, no. 2 (2009): 161-178; Porter, "What Exactly is Theological Interpretation of Scripture," 234-267.

${ }^{7}$ Hendry Ongkowidjojo, “Theological Interpretation of Scripture: Suatu Pengantar," Jurnal Amanat Agung 9, no. 1 (2013): 41-66. Ada satu lagi tulisan tentang pendekatan TIS yang ditulis oleh orang Indonesia, yaitu Nathaniel 
karakteristik pendekatan TIS, yaitu: menegaskan peran penting doktrin di dalam penafsiran, melakukan penafsiran secara kanonik, menafsir dalam dialog dengan penafsir pramodern, tetap menerima peran penting metode historis-kritis, menerima ragam tafsir yang bertanggung jawab, mengakui peran gereja sebagai konteks penafsiran, dan melihat aplikasi sebagai sebuah keniscayaan penafsiran. ${ }^{8}$ Pemaparan Ongkowidjojo ini tentu memberikan gambaran yang dapat menolong pembaca memahami bentuk dan rupa pendekatan TIS, khususnya bagi mereka yang baru pertama kali berkenalan dengan subjek ini. Namun, diperlukan bahan-bahan tambahan untuk lebih mendalami natur dan esensi pendekatan TIS itu sendiri.

Tulisan ini hendak menelisik lebih dalam bentuk dan rupa TIS yang sudah diguratkan dalam berbagai literatur, untuk menemukan berbagai keyakinan dan pemikiran yang melatarbelakangi dan mendasari prinsip dan praktik pendekatan TIS. Pada dasarnya, terlihat bahwa pendekatan TIS adalah pendekatan pembacaan yang melibatkan dua konteks, yaitu konteks teologis dan konteks eklesial. Akan dipaparkan kepercayaan-kepercayaan atau prasuposisi utama yang ada di balik kedua konteks tersebut, tetapi sebelumnya akan dipetakan terlebih dahulu pergerakan perkembangan TIS baik secara historikal maupun konseptual. ${ }^{9}$

Gray Sutanto, "Toward a Reformed Theological Interpretation of Scripture," IJT 1, no. 1 (2013): 103-116. Namun, tulisan kedua ini ditulis dengan menggunakan bahasa Inggris.

\section{${ }^{8}$ Ibid., 45-46.}

${ }^{9}$ Perkenalan tentang TIS akan berkaitan erat dengan sejarah perkembangannya karena definisi dan bentuk pendekatan TIS terus mengalami perkembangan seiring dengan sejarahnya. Sebenarnya tidak ada kejelasan kapan istilah TIS ini mulai digunakan. Konsepsi dasar TIS sendiri mengenai "menafsirkan Alkitab secara teologis" sudah banyak tersebar di berbagai tulisan dengan istilah senada seperti "hermeneutik teologis," "pembacaan teologis," atau "eksegesis teologis" (lih. mis. Kevin J. Vanhoozer, The Drama of Doctrine: A Canonical-Linguistic Approach to Christian Theology [Louisville: Westminster John Knox, 2005]; Anthony Thiselton, The Two Horizons: New Testament Hermeneutics and Philosophical Description with Special Reference to Heidegger, Bultmann, Gadamer, and

\section{SELAYANG PANDANG PENDEKATAN TIS: KONSTRUKSI BENTUK DAN SEJARAH PERKEMBANGANNYA}

Sejarah perkembangan TIS tidak dapat dilepaskan dari pangkal latar belakangnya, yang oleh kebanyakan literatur diarahkan kepada ceramah inaugurasi Johann Philipp Gabler pada 1787, An Oration on the Proper Distinction between Biblical and Dogmatic Theology and the Specific Objectives Each. Ceramah ini kemudian dinilai sebagai pedang pemisah antara studi historis dengan studi normatif, eksegesis biblika dengan teologi sistematika-dan implikasinya-dunia akademik dan pelayanan praktis. $^{10}$ Kebutuhan akan pembacaan religius dan teologis terhadap Kitab Suci yang melampaui hegemoni historis-kritis menelurkan ide-ide dasar TIS, yang menurut Joel B. Green, merupakan ketidakpuasan terhadap status quo dari studi biblika yang bersifat akademis sekaligus pengembangan caracara untuk mendengar suara Allah. ${ }^{11}$

Pembacaan teologis-religius sebagai alternatif (atau kritik) di tengah studi historis-kritis yang cenderung melakukan "desakralisasi teks,"

Wittgenstein [Grand Rapids: Eerdmans, 1980]; Anthony Thiselton, New Horizons in Hermeneutics: The Theory and Practice of Transforming Biblical Reading [Grand Rapids: Zondervan, 1992]).

${ }^{10}$ Rujukan kepada Gabler muncul misalnya pada Ongkowidjojo, "Theological Interpretation," 36-37. Signifikansi ceramah Gabler dalam studi biblika dan teologi, lih. Charles H.H. Scobie, The Ways of Our God: An Approach of Biblical Theology (Grand Rapids: Eerdmans, 2003), 5, 15-16; Craig G. Bartholomew, "Biblical Theology," dalam DTIB, 84-90. Sebenarnya masih terbentang jarak yang panjang antara ceramah Gabler dengan pendekatan TIS, misalnya saja kehadiran studi teologi biblika kanonik yang dimotori Brevard S. Childs di tengah-tengahnya (lih. Hendrawan Wijoyo, "Analisis Pendekatan Kanonik Brevard Childs, Evaluasi, dan Perkembangannya dalam Studi Biblika,” skripsi, STT SAAT, 2015).

${ }^{11}$ Joel B. Green, “The (Re-)Turn to Theology,” JTI 1, no. 1 (2007): 1-3, mengutip Kevin J. Vanhoozer, "Introduction: What Is Theological Interpretation of the Bible?," dalam DTIB, 19-25; bdk. Moberly, "What Is Theological Interpretation of Scripture," 163; Sutanto, "Reformed," 108.

${ }^{12}$ Istilah ini digunakan dalam Kevin J. Vanhoozer, "Ascending the Mountain; Singing the Rock: Biblical Interpretation Earthed, Typed, and Transfigured," Modern Theology 28, no. 4 (Oktober 2012): 782, merujuk kepada ekses 
oleh sebagian peneliti TIS dilansir muncul sejak tafsiran Surat Roma (Dër Romerbrief) yang ditulis oleh Karl Barth pada 1918-1921 dan dijuluki sebagai "bom yang diledakkan di arena bermain para teolog" yang mengubah arus sejarah teologi modern hingga kini. ${ }^{13} \mathrm{Di}$ dalam tafsiran ini, Barth berkeinginan untuk menafsir melalui dan melampaui sejarah, kepada "roh" dari teks itu sendiri, yaitu perkataan Roh Kudus sendiri. ${ }^{14}$ Keinginan ini muncul setelah Barth sendiri bergulat dengan konteks kehidupan dan pelayanannya sebagai pendeta jemaat di Safenwil. ${ }^{15}$ Ia melihat

dari penekanan studi historis-naturalis, yaitu pengabaian (atau penolakan) terhadap dimensi sakralitas Kitab Suci sebagai tulisan dari dan milik Allah. Meskipun demikian, perlu dipahami bahwa dalam artikel tersebut, Vanhoozer merujuk kepada filsafat nominalisme abad ke-14 setelah Thomas Aquinas, sementara yang dimaksud dalam tulisan ini lebih kepada historis-kritis modern khas pendidikan Jerman-yang kemudian diadopsi pula oleh Amerika-sebagai buah ceramah Gabler (lih. Daniel J. Treier, Introducing Theological Interpretation of Scripture: Recovering a Christian Practice [Grand Rapids: Baker Academic, 2008], 13-14).

${ }^{13}$ Treier, Theological Interpretation, 14-15; Green, "The (Re-)Turn to Theology," 1; Mary Kathleen Cunningham, "Karl Barth," dalam Christian Theologies of Scripture: A Comparative Introduction, ed. Justin S. Holcomb (New York: New York University Press, 2006), 183; Stephen Westerholm dan Martin Westerholm, Reading Sacred Scripture: Voices from the History of Biblical Interpretation (Grand Rapids: Eerdmans, 2016), 360.

${ }^{14}$ Karl Barth, kata pengantar pada edisi pertama, The Epistles to the Romans, terj. Edwyn C. Hoskyns (Oxford: Oxford University Press, 1968), 1.

\footnotetext{
${ }^{15}$ Sebenarnya ada beberapa konteks yang menjadi latar pergumulan teologis Barth di masa-masa ini. Pertama, ia menemukan kebuntuan dari teologi dan tafsir historis-kritis modern yang sampai pada akhirnya sama sekali mengabaikan sakralitas Kitab Suci. Kedua, ia kecewa dengan buah-buah teologi modern, khususnya ketika mendapati dosen-dosen teologi modern junjungannya mendukung Perang Dunia I secara vokal. Ketiga, ia berhadapan langsung dengan berbagai pergumulan hidup umat di dalam pelayanan kependetaannya di Safenwil. Pergumulan-pergumulan teologis-eksistensial ini akhirnya menggiringnya untuk "kembali kepada Kitab Suci" dan menemukan "dunia aneh baru di dalam Kitab Suci" (lih. Richard E. Burnett, Karl Barth's Theological Exegesis: The Hermeneutical Principles of the Römerbrief Period [Grand Rapids: Eerdmans, 2001], 265-275; Gordon H. Clark, Karl Barth's Theological Method, ed. ke-2 [New Mexico: The Trinity Foundation, 1997], viii; Donald Wood, Barth's Theology of Interpretation, Barth Studies Series [Burlington: Ashgate, 2007], 11-12; Westerholm dan Westerholm, Reading, 358$359,361)$.
}

bahwa teks Alkitab paling baik dibaca dengan menghayati naturnya sebagai tulisan yang bersifat teologis dan religius. Meskipun begitu, pendekatan hermeneutisnya bukan semata-mata sebuah bentuk konfrontasi terhadap metode historis-kritis, melainkan sebuah bentuk kristalisasi dari kemampuan eksegesis teks dan tafsir dokumen-dokumen teologi Reformed yang dipegangnya. ${ }^{16}$ Bagi Barth, metode historis-kritis adalah "bagian pendahuluan" atau tahap pertama dari keseluruhan rangkaian proses hermeneutik. ${ }^{17}$ Tahapan selanjutnya, yang juga merupakan porsi besar dalam aktivitas hermeneutik, adalah apa yang disebutnya sebagai "upaya memahami," atau membaca teks dengan melibatkan konteks dan isu-isu kontemporer dalam dunia penafsir untuk memahami makna teks yang lebih utuh dan penuh sebagai implikasi dari doktrin inspirasi Kitab Suci. ${ }^{18}$

Di samping pendukung narasi kelahiran TIS dari Barth, ada pula pihak-pihak yang memetakan kelahiran TIS pada masa-masa yang lebih awal. Angus Paddison misalnya, menyatakan bahwa kemunculan TIS dalam tafsiran

${ }^{16}$ Denni Boy Saragih, "Disruptive Presence: The Ontology, Theology and Ethics of Reading the Bible as Scripture in Karl Barth's Theological Exegesis," (disertasi, University of Edinburgh, 2015), 50-51. Menurut Burnett, ada empat prinsip mendasar yang diterapkan Barth untuk menafsirkan teks. Pertama, ia berfokus kepada natur utama teks yang adalah perkataan Allah sehingga keberadaan Allah yang kekal itu menjadi semacam paradigma kontrol bagi penafsiran. Kedua, pembaca harus "terlibat" di dalam dunia penulis teks sebagai upaya memahami makna. Ketiga, pembaca harus membaca "dengan lebih banyak perhatian dan kasih" ketimbang yang dilakukan oleh para ilmuwan modern atau kritikus historis murni. Terakhir, ia bersikukuh pada "pembacaan yang lebih selaras dengan makna Alkitab itu sendiri" (disarikan dari Burnett, Theological Exegesis, bab 3-5).

${ }^{17}$ Penggunaan metode historis-kritis sebagai langkah utama ini terlihat dari: (1) diskusi teks PB bahasa Yunani dengan membandingkan antara terjemahan pribadinya dari bahasa Yunani ke bahasa Jerman dan terjemahan Yunani Nestle-Aland yang merepresentasikan kesarjanaan biblika abad ke-19; (2) studi leksiografi Yunani dengan menggunakan leksikon Cremer-Kögel's yang diakui terbaik pada masa itu; serta (3) penggunaan buku-buku tafsiran lain yang berasal dari berbagai latar belakang pemikiran dan corak teologi (Saragih, "Disruptive Presence," 51-57).

${ }^{18}$ Treier, Theological Interpretation, 17; Saragih, "Disruptive Presence," 57-68. 
Barth lebih merupakan sebuah pembaharuan atau penamaan ulang daripada kemunculan perdana, karena baginya esensi TIS yang merupakan pembacaan Kitab Suci dalam konteks eklesial sama sekali tidak pernah alpa dari sejarah gereja. ${ }^{19}$ Penerapan TIS di dalam sejarah gereja terwujud misalnya di dalam khotbah, pembacaan teks secara publik, sakramen, dan aksi-aksi karitas. Robert W. Jenson juga mengemukakan bahwa penafsiran secara teologis sudah terjadi sejak gereja mula-mula dalam rupa liturgi gerejawi, devosi, dan katekisasi. ${ }^{20}$ Dengan demikian, agaknya dapat disimpulkan bahwa TIS secara substansial, atau esensial, sebenarnya sudah diterapkan di dalam kehidupan bergereja sejak awal sejarah kekristenan, tetapi TIS secara formal, atau dengan kesadaran teologis dan eksegetikal tertentu, dibangkitkan kembali di abad ke-20 seiring dengan kebutuhan pembacaan alternatif di tengah kebuntuan-kebuntuan dalam metode historis-kritis modern. Penelusuran sejarah ini memberikan kesan bahwa TIS memiliki dua corak utama, yaitu pembacaan dalam konteks gerejawi dan pembacaan yang melampaui pendekatan historis-kritis.

Perlu diakui bahwa belum ada semacam finalitas definisi dan langkah-langkah di dalam TIS karena pendekatan ini pun masih terus berkembang. ${ }^{21}$ Namun, banyak upaya yang sudah dilakukan untuk memberi identitas kepada sketsa bentuk yang sudah tampak semakin jelas ini. Beberapa karya yang mula-mula membuka ruang diskusi dan pemikiran bagi pendekatan TIS misalnya Text, Church, and the World oleh Francis Watson, ${ }^{22}$ Engaging Sc-

${ }^{19}$ Angus Paddison, "The History and Reemergence of Theological Interpretation,” dalam Manifesto, 1, 28.

${ }^{20}$ Robert W. Jenson, "Hermeneutics and the Life of the Church," dalam Reclaiming the Bible for the Church, ed. Carl E. Brateen dan Robert W. Jenson (Grand Rapids: Eerdmans, 1995), 90-91.

${ }^{21}$ Gregg R. Allison, "Theological Interpretation of Scripture: An Introduction and Preliminary Evaluation," SBJT 14, no. 2 (2010): 29.

${ }^{22}$ Francis Watson, Text, Church, and World: Biblical Interpretation in Theological Perspective (Grand Rapids: Eerdmans, 1994). Dalam buku ini, Watson mengemukakan bahwa kerja eksegesis harus juga memperhatikan dan bersinggungan dengan isu-isu teologis yang muncul dari ripture oleh Stephen Fowl, ${ }^{23}$ Is There a Meaning in This Text ${ }^{24}$ dan First Theology dari Kevin J. Vanhoozer ${ }^{25}$ Definisi mula-mula terhadap pendekatan TIS juga muncul dari Vanhoozer dalam kata pengantarnya pada Dictionary for Theological Interpretation of the Bible. ${ }^{26} \mathrm{Na}-$ mun, definisi yang diberikan hanya sebatas apa yang bukan dan tidak dimaksud pendekatan TIS. Pertama, meskipun pengakuan iman dan tradisi teologis penafsir merupakan sesuatu yang penting dalam penafsiran, TIS pada naturnya tidak berusaha untuk memasukkan sistem teologi atau kerangka konfesi iman dari tradisi tertentu ke dalam teks Kitab Suci untuk mendapatkan justifikasi atau

teks Alkitab yang dibaca dalam konteks gerejawi, kebudayaan, dan sosial-politik kontemporer (sehingga locus pembacaan yang berbeda dapat mendiskusikan isu teologis yang berbeda pula). Bagi Watson, eksegesis dan teologi selalu bersifat dialektis. Pembacaan teks pasti akan dipengaruhi oleh lensa teologi (atau ideologi) pembaca, dan hasil pembacaan pun akan merekonstuksi lensa tersebut terus-menerus. Paparan Watson ini cukup melawan arus eksegetikal pada masa itu yang menganggap lensa teologis atau ideologi pembaca adalah bias yang harus disingkirkan demi kejernihan penafsiran.

${ }^{23}$ Stephen E. Fowl, Engaging Scripture: A Model for Theological Interpretation (Oxford: Blackwell, 1998). Tulisan Fowl menekankan pentingnya kembali kepada natur Alkitab sebagai Kitab Suci orang Kristen dan tidak bias dibaca secara netral. Ia juga menunjukkan kelemahankelemahan pendekatan teologi biblika yang meskipun berupaya untuk menyintesis pandangan teologis penulis atau corpus kitab tertentu, tetapi masih belum dapat membentuk kerangka teologis bagi penafsiran khususnya dalam memahami kesatuan Kitab Suci dan kontinuitas narasi Allah antara dunia Kitab Suci dan dunia pembaca masa kini.

${ }^{24}$ Kevin J. Vanhoozer, Is There a Meaning in This Text?: The Bible, The Reader, and the Morality of Literary Knowledge (Grand Rapids: Zondervan, 1998). Buku ini merupakan pemikiran mula-mula Vanhoozer tentang hermeneutik teologis, meskipun pada waktu itu ia belum secara khusus mengkristalisasikan pandangannya menjadi sebuah "bentuk" pendekatan. Dalam buku ini, Vanhoozer mendiskusikan bahwa semua isu dalam penafsiran sejatinya adalah isu teologis. Ia memberi apresiasi kepada dekonstruksionisme dan hermeneutika filosofis, khususnya filsafat bahasa, dan menyatakan keniscayaan pemberian ruang bagi pembaca dalam menemukan makna.

${ }^{25}$ Kevin J. Vanhoozer, First Theology: God, Scripture, and Hermeneutics (Downers Grove: InterVarsity, 2002). Argumentasi utama dalam buku ini adalah bahwa doktrin seseorang tentang Allah akan memengaruhi caranya memandang dan menafsir Kitab Suci.

${ }^{26}$ Kevin J. Vanhoozer, “Introduction,” dalam DTIB, 19. 
legitimasi semata. Kedua, TIS juga bukan upaya memasukkan teori hermeneutik umum atau teori penafsiran yang biasa dipakai bagi teks-teks lain ke dalam teks Kitab Suci karena pada dasarnya Kitab Suci adalah tulisan ilahi, tidak sama dengan buku-buku lain. Terakhir, TIS juga tidak hanya mengulangi kritik historis, literaris, atau sosiologis yang lebih banyak berurusan dengan dunia "di belakang," "mengenai," atau "di depan" teks, tetapi TIS menekankan bahwa kegiatan menafsir sejatinya merupakan partisipasi umat Allah dalam karya keselamatan yang masih berlangsung hingga kini. ${ }^{27}$

Setelahnya, mulai bermunculan buku pengantar yang mempermudah pembaca untuk memahami dan mengenali wajah pendekatan TIS. Ada tiga buku pengantar yang dapat dikatakan paling menolong untuk berkenalan dengan pendekatan TIS. Pertama, Seized by the Truth dari Joel Green, yang tesis utamanya adalah menggaungkan kembali pembacaan Alkitab sebagai Kitab Suci Kristen dan harus berujung pada dimensi normatif, yaitu pembentukan pola pikir dan cara hidup umat Kristen. ${ }^{28}$ Kedua, Introducing Theological Interpretation dari Daniel J. Treier, ${ }^{29}$ yang oleh Stanley Porter bahkan dinobatkan sebagai pengantar yang dapat dikatakan paling lengkap untuk subjek ini. ${ }^{30}$ Dalam buku ini, Treier memberikan napak tilas sejarah TIS dan kontribusinya bagi pergumulan hermeneutika posmodern yang sangat dipengaruhi oleh pembacaan-pembacaan komunal. Treier juga menunjukkan konsensus-konsensus dalam pendekatan TIS berikut tantangan-tantangan yang masih harus dijawab, misalnya relasi TIS dengan teologi biblika dan hermeneutika

\footnotetext{
${ }^{27}$ Ibid.

${ }^{28}$ Joel B. Green, Seized by the Truth: Reading the Bible as Scripture (Nashville: Abingdon, 2007), 3, 5. Pembacaan seperti ini, bagi Green, ideal apabila dilakukan dalam konteks eklesial, dibentuk oleh konfesi teologi yang sudah diyakini dalam tradisi tertentu sepanjang sejarah, diwarnai oleh perjumpaan-perjumpaan kritis dengan pembacaan dari tradisi lain, dan dituntun oleh Roh Kudus sendiri.

${ }^{29}$ Treier, Theological Interpretation.

${ }^{30}$ Lih. Porter, "What Exactly is Theological Interpretation of Scripture," 237-239.
}

umum. Buku pengantar ketiga yang juga tak kalah penting adalah The Word of God for the People of God dari J. Todd Billings. ${ }^{31}$ Billings menegaskan bahwa pendekatan TIS bukanlah sebuah metode tunggal atau disiplin khusus yang dapat diterapkan secara pragmatis, melainkan TIS adalah ragam praktik dengan cakupan luas yang dilakukan oleh berbagai kelompok umat Allah dalam membaca dan menggumulkan teks Kitab Suci sebagai penyataan diri Allah dan bagian dari sejarah keselamatan.

Produk dari pendekatan TIS mulai terlihat setelah terbitnya sebuah kumpulan esai yang menjadi pengantar untuk terbitan seri Two Horizons Commentary, berjudul Between Two Horizons, pada 2000. ${ }^{32}$ Intensi penerbitan kumpulan esai dan seri tafsiran ini adalah untuk mengintegrasikan kembali eksegesis biblika dengan teologi kontemporer bagi pelayanan kepada gereja Allah. ${ }^{33}$ Tafsiran Two Horizons diperkenalkan sebagai jalan ketiga bagi ketidakpuasan terhadap hegemoni historis-kritis dan kurang lengkapnya pendekatan teologi biblika, dengan menyediakan eksposisi teologis terhadap teks, analisis terhadap kontribusi teks bagi teologi biblika, dan refleksi teologis kontemporer yang lebih luas. ${ }^{34}$ Meskipun di kemudian hari seri tafsiran Two Horizons ini diperdebatkan oleh berbagai kalangan sarjana biblika karena dinilai tidak mencerminkan sebuah karya eksegesis yang murni, tetapi penerbitannya menunjukkan kehausan sekaligus upaya untuk memperkecil sekat antara studi biblika "murni" dan studi teologi "sistematik." Sintesa keduanya, secara sederhana, dapat dipahami sebagai modelmodel pembacaan teologis. Keseriusan terhadap pendekatan TIS juga terlihat semakin

${ }^{31} \mathrm{~J}$. Todd Billings, The Word of God for the People of God: An Entryway to the Theological Interpretation of Scripture (Grand Rapids: Eerdmans, 2010).

${ }^{32}$ Joel B. Green dan Max Turner, ed., Between Two Horizons: Spanning New Testament Studies and Systematic Theology (Grand Rapids: Eerdmans, 2000).

\footnotetext{
${ }^{33}$ Max Turner dan Joel B. Green, "New Testament Commentary and Systematic Theology: Strangers or Friends?," dalam Between Two Horizons, 2.

${ }^{34}$ Ibid., 11.
} 
meningkat dengan munculnya jurnal akademis bertajuk Journal for Theological Interpretation pada tahun 2007, yang menunjukkan bahwa subjek TIS sudah dipercakapkan dalam taraf akademik dan bukan hanya menjadi sebuah wacana pemikiran yang acak sifatnya.

Sampai hari ini, semakin banyak tokoh dan karya yang mencoba memperjelas definisi, bentuk, dan tugas kerja pendekatan TIS. ${ }^{35}$ Definisi-definisi yang diberikan untuk pendekatan TIS pun beragam, mulai dari yang sangat filosofis hingga yang sangat praktis. ${ }^{36}$ Dari berbagai sumber yang dapat diteliti, ada beberapa kesamaan yang dapat ditarik. Pertama, pendekatan TIS mencoba mengembalikan keyakinan penafsir terhadap natur Alkitab yang merupakan Kitab Suci milik orang Kristen, yang sifatnya sakral dan tidak netral, sehingga cara membacanya pun semestinya berbeda dengan pembacaan buku-buku lain. Kedua, pendekatan TIS menunjukkan bahwa prasuposisi teologi seseorang merupakan

${ }^{35}$ Lih. mis. Mark Alan Bowald, "The Character of Theological Interpretation of Scripture," IJST 12, no. 2 (April 2010): 168; John Webster, "Editorial," IJST 12, no. 2 (April 2010): 116; Kevin J. Vanhoozer, "Exegesis I Know, and Theology I Know, But Who Are You?': Acts 19 and the Theological Interpretation of Scripture," dalam Theological Theology: Essays in Honor of John B. Webster, ed. R. David Nelson, Darren Sarisky dan Justin Stratis (Bloomsbury: T\&T Clark, 2015), 291. Buku lain yang juga penting dibaca apabila hendak mendalami natur dan substansi pendekatan TIS adalah Mark Alan Bowald, Rendering the Word in Theological Hermeneutics: Mapping Divine and Human Agency, Studies in Historical and Systematic Theology (Bellingham: Lexham, 2015); Ephraim Radner, Time and The Word: Figural Reading of the Christian Scripture (Grand Rapids: Eerdmans, 2016); D. Christopher Spinks, The Bible and the Crisis of Meaning: Debates on the Theological Interpretation of Scripture (London: T\&T Clark, 2007), 7; Craig A. Carter, Interpreting Scripture With the Great Tradition: Recovering the Genius of Premodern Exegesis (Grand Rapids: Baker, 2018). Judul yang terakhir ini cukup kontroversial karena oleh beberapa pihak dianggap "terlalu berlebihan" dan kurang tepat dalam membaca pandangan hermeneutik teologis dari John Webster. Namun, bab-bab awal dari buku ini, khususnya bagian mengenai hermeneutik teologis, perlu dipelajari oleh peminat serius.

\footnotetext{
${ }^{36}$ Ongkowidjojo sendiri, yang tulisannya dirujuk di awal tulisan ini, mendefinisikan pendekatan TIS sebagai "suatu metode tafsir Kitab Suci yang bersifat menyeluruh, yang memberikan tempat sepatutnya kepada doktrin dan aplikasi, tanpa mengabaikan pemakaian alat-alat bantu eksegesis modern" ("Theological Interpretation," 35).
}

salah satu unsur determinatif dalam penafsiran. Ketiga, pendekatan TIS memandang kegiatan penafsiran sebagai bentuk partisipasi umat Allah di dalam sejarah keselamatan yang masih terus berlangsung sehingga unsur yang perlu diperhatikan dalam penafsiran bukan hanya teks dan penulis, tetapi juga pembaca itu sendiri. Keempat, pendekatan TIS secara sederhana memberi ruang yang sama besar bagi fungsi normatif atau aplikasi teks dalam kehidupan pembaca, bukan hanya bagi fungsi deskriptif atau hasil eksegesis dari teks yang dibaca sebagaimana yang berlaku dalam "studi biblika" selama ini.

Ada juga beberapa hal yang perlu dipahami sebagai sebuah catatan awal sebelum lebih jauh menelusuri natur dan prasuposisi-prasuposisi pembentuk pendekatan TIS. Pertama, TIS bukan sebuah metode atau langkah-langkah yang dapat diterapkan secara metodik dan seragam, melainkan TIS lebih merupakan sebuah pendekatan, cara berpikir, atau kerangka kerja (framework) di dalam menafsir Kitab Suci. Cara terbaik untuk memahami TIS, menurut John Webster, adalah dengan menerapkannya. ${ }^{37}$ Argumentasi ini memang terkesan sirkular karena bagaimana mungkin kita dapat menerapkan sesuatu yang belum ada atau belum jelas metodenya? Namun, berdasarkan keyakinan Webster ini, justru kita diperkenalkan terhadap natur pendekatan TIS itu sendiri, yaitu beragam praktik di dalam membaca dan menggumulkan Alkitab sebagai pesan Allah bagi kehidupan kita sebagai umat-Nya di masa kini.

Kedua, pendekatan TIS sendiri memiliki banyak spektrum yang bisa dilihat dari berbagai tolok ukur sehingga diskusi tentang TIS secara luas agaknya lebih tepat dipahami sebagai "interpretasi-interpretasi teologis" (jamak) terhadap Kitab Suci, dan ketika kita membahas "sebuah" pendekatan TIS, kita perlu menyamakan pandangan terlebih dahulu mengenai spektrum pendekatan TIS mana yang dibahas dari cakupannya yang begitu luas dan

\footnotetext{
${ }^{37}$ Webster, "Editorial," 116.
} 
beragam. ${ }^{38}$ Di dalam diskursus akademik sendiri misalnya, Treier memetakan pendekatan TIS ke dalam tiga mazhab berdasarkan pemikiran tiga "pemain utama," yaitu Francis Watson, Stephen Fowl, dan Kevin J. Vanhoozer yang mewakili dua aliran sekolah pemikiran, yaitu Yale dan Duke. ${ }^{39}$ Ketiga mazhab ini berbeda dalam memandang unsur mana yang perlu diberi fokus lebih dalam penafsiran. Watson lebih banyak menekankan pentingnya suara dari dalam teks itu sendiri sehingga mengutamakan studi intratekstualitas dalam teks, Fowl lebih menekankan unsur pembaca yang menemukan sendiri makna bagi konteks kehidupan partikular yang berbeda satu dengan yang lain, sementara Vanhoozer, yang agaknya paling bisa diterima oleh kalangan Injili, menekankan pentingnya makna dari pengarang sebagai kontrol sekaligus muara bagi penafsiran teologis yang lebih luas. ${ }^{40} \mathrm{Pe}$ mahaman kepelbagaian spektrum ini penting agar pembahasan mengenai pendekatan TIS tidak berlangsung secara sempit dan menjadi generalisasi. Menariknya, terlepas dari segala perbedaan spektrum yang ada, ketiga mazhab ini tetap sama-sama memberi penghormatan terhadap natur teks Kitab Suci sebagai tulisan sakral dan Allah sebagai pengarang utama yang berbicara sampai hari ini kepada pembaca. Dari persamaan-persamaan inilah muncul berbagai prasuposisi umum yang dapat diteliti sebagai natur atau "DNA" bagi pendekatan TIS itu sendiri.

\footnotetext{
${ }^{38}$ Mark Alan Bowald di dalam bukunya Rendering the Word misalnya, membuat klasifikasi dan pemetaan pemikir-pemikir TIS berdasarkan proporsi keterlibatan unsur Ilahi dan unsur manusia dalam penulisan dan penafsiran teks. Pemetaan lain juga dapat dibuat, misalnya, berdasarkan sejauh mana tokoh-tokoh TIS ini memberi ruang bagi pendekatan historis-kritis.
}

${ }^{39}$ Daniel Treier, "What is Theological Interpretation? An Ecclesial Reduction," IJST 12, no. 2 (2010): 146-148. Kelompok Yale di sini misalnya Christopher Seitz dan penulis-penulis lain dalam festschrift Theological Exegesis: Essays in Honor of Brevard S. Childs (Grand Rapids: Eerdmans, 1999), sementara kelompok kerja The Scripture Project yang menelurkan buku The Art of Reading Scripture editan Richard Hays dan Ellen F. Davis dianggap mewakili warna pemikiran sekolah Duke.

${ }^{40}$ Ibid.

\section{PRASUPOSISI-PRASUPOSISI POKOK DI BALIK RUPA PENDEKATAN TIS}

Dari berbagai definisi dan prinsip-prinsip kerja pendekatan TIS yang sudah dipaparkan oleh banyak tokoh, dapat ditelusuri beberapa keyakinan dan prasuposisi utama yang dipegang oleh semua tokoh tersebut. ${ }^{41}$ Keyakinan dan prasuposisi tersebut sangat mungkin terkesan beririsan atau serupa dengan pendekatan tafsir lain yang mendahuluinya, tetapi kita dapat menilik dasar berpikir yang jelas akan membedakannya dari keyakinan-keyakinan tafsir yang lain. Karena pendekatan TIS pada dasarnya dilakukan dalam konteks teologis dan konteks eklesial, maka prasuposisi-prasuposisi utama yang melatarbelakanginya pun akan dibahas dalam kerangka dua konteks tersebut.

\section{Pembacaan dalam Konteks Teologis}

\section{Teks Kitab Suci adalah Tulisan Sakral yang Berbeda dari Buku Biasa}

Salah satu dampak dari beragam bentuk penafsiran kritis terhadap Alkitab setelah Pencerahan adalah "terpinggirkannya" kesadaran teologis tentang natur Alkitab sebagai penyataan ilahi. ${ }^{42}$ Prasuposisi yang menjadi semacam prinsip kontrol dalam penafsiran adalah pembacaan Alkitab seperti buku biasa. ${ }^{43}$ Benjamin Jowett, misalnya, menegaskan bahwa seorang penafsir yang baik perlu "membuka matanya" untuk melihat hal yang

\footnotetext{
${ }^{41}$ Beberapa tokoh mencoba merumuskan prinsip-prinsip TIS dalam bentuk tesis, misalnya "Nine Theses on the Interpretation of Scripture," dalam Davis dan Hays, The Art, 1-5 yang kemudian ditambahkan dengan lima tesis suplemental dalam Bowald, "The Character," 181-182; Kevin J. Vanhoozer, "Ten Theses on the Theological Interpretation of Scripture," Modern Reformation 19, no. 4 (2010): 16-19. Prinsip-prinsip TIS yang disajikan dalam bagian ini merupakan sintesis dan klasifikasi dari tesis-tesis di atas ditambah sumber-sumber lainnya.

${ }^{42}$ Vanhoozer, First Theology, 128. Keterpinggiran ini dapat disinyalir, misalnya, dalam penekanan bahwa bahasa dan tradisi teks Kitab Suci berakar pada sejarah manusia daripada "hembusan nafas Allah" (2Tim. 3:16).

${ }^{43}$ Benjamin Jowett, "On the Interpretation of Scripture," Essays and Reviews, ed. ke-7 (London: Longman, 1861), 7.
} 
sebenarnya terjadi di dalam teks dengan tidak mengandalkan tradisi konvensional. ${ }^{44}$

Seperti sebuah antitesis dari keyakinan tersebut, TIS berpendapat bahwa Alkitab adalah Kitab Suci Kristen yang mempunyai karakter unik dan sama sekali tidak dapat dibaca seperti buku biasa atau dokumen historis pada umumnya. ${ }^{45}$ Vanhoozer berpendapat bahwa jika kita ingin menerapkan konsep "membaca Alkitab seperti buku biasa" yang pada dasarnya menekankan penilaian objektif terhadap teks, maka kita perlu adil di dalam memberikan penilaian objektif terhadap natur teks Kitab Suci yang sejatinya adalah perkataan Allah sendiri. ${ }^{46}$ Lebih tajam lagi, di dalam sepuluh tesis yang dipublikasikannya belakangan, ia menandaskan bahwa penerimaan terhadap natur teologis Kitab Suci berarti, sekaligus mensyaratkan, sebuah penolakan terhadap "ateisme metodologis" yang memandang teks hanya memiliki sejarah netral dan harus didekati secara kritis-natural. ${ }^{47}$ Nathaniel Gray Sutanto turut menyuarakan:

TIS presupposes the necessity of acknowledging the character of God and Scripture to be able to interpret it rightly. It demands that Scripture must be read according to the "rule of faith" and that a neutral reading of Scripture is impossible. ... History does not make a claim upon our lives. Scripture does. From the very beginning, when one comes to read the Bible one is immediately encountered by Yahweh, a God who demands a total allegiance to Him. ${ }^{48}$

Kesadaran bahwa Kitab Suci pada dasarnya adalah tulisan teologis (bukan semata historis) dan bersifat sakral karena ditulis oleh Allah sendiri tentu akan menghasilkan

\footnotetext{
${ }^{44}$ Jowett, "On the Interpretation of Scripture," 7. 109.

${ }^{45}$ Bowald, "The Character," 181; Sutanto, "Reformed,"

${ }^{46}$ Kevin J. Vanhoozer, Is There a Meaning in This Text?: The Bible, The Reader, and the Morality of Literary Knowledge [Grand Rapids: Zondervan, 1998], 455.

${ }^{47}$ Vanhoozer, “Ten Theses,” 17.

${ }^{48}$ Sutanto, "Reformed," 109.
}

penafsiran yang juga bersifat teologis, tidak semata-mata historis, apalagi netral tanpa muatan keyakinan iman tertentu. Tentu saja ini tidak berarti akurasi historis di dalam teks Kitab Suci itu sendiri diragukan, melainkan penulisannya dilakukan dalam perspektif teologi umat Allah.

Keyakinan bahwa Kitab Suci merupakan tulisan sakral juga mensyaratkan keterlibatan afeksi dan meditasi di dalam pembacaan. Pembacaan ini tidak berangkat dari kecurigaan, melainkan ketundukan dan penerimaan terhadap perkataan Allah. ${ }^{49}$ Kitab Suci dipandang sebagai subjek yang dapat menyatakan sesuatu tentang pembaca sehingga praktik penafsiran itu dapat dipandang sebagai sebuah percakapan yang sehat (mutual) antara dua subjek, sebagaimana dinyatakan Billings:

When we seek to understand a text, we should not treat it as an object over which we exercise control (in a subject-object relation). Instead, reading a text is more like a healthy conversation, a subject-subject relationship in which we do not treat the other person as an object to be understood and thus dominated. In a healthy conversation we display an openness toward the person's claim on us: It is a genuine listening. ${ }^{50}$

Implikasinya, pembaca Kitab Suci perlu membawa seluruh kehidupannya di dalam pembacaan untuk dapat dijumpai oleh Allah melalui pembacaan dan diperbarui terus-menerus menuju kesempurnaan yang dikehendaki Allah. $^{51}$

\footnotetext{
${ }^{49}$ Miroslav Volf, Captive to the Word of God: Engaging the Scripture for Contemporary Theological Reflection (Grand Rapids: Eerdmans, 2010), 34; bdk. David Kelsey, Eccentric Existence: A Theological Anthropology (Louisville: Westminster John Knox, 2009), 140-156.

${ }^{50}$ Billings, The Word of God, 42; bdk. Andrew Louth, Discerning the Mystery: An Essay on the Nature of Theology (Oxford: Oxford University Press, 1983), 39-41.

${ }^{51}$ Billings, The Word of God, 41.
} 
Teks Kitab Suci adalah Bentuk Komunikasi Ilahi di Sepanjang Sejarah

Hermeneutika modern kerap memandang bahwa penulis buku-buku di dalam Kitab Suci berbicara pada dan untuk pembaca di masa lampau. Dalam keyakinan yang demikian, pada umumnya pembaca teks masa kini diajak untuk menemukan makna asali yang berlaku bagi pembaca pertama di masa lampau, kemudian baru menemukan aplikasinya bagi kehidupan di zaman ini. Ada pula pandangan lain yang beranggapan bahwa pengarang teks "sudah mati" atau tidak terlalu berperan di dalam menentukan makna, dan teks berbicara di dalam dan melalui dirinya sendiri berdasarkan fitur-fitur yang dapat diamati seperti bentuk atau alur narasi. ${ }^{52}$

Berbeda dengan kedua keyakinan tersebut, TIS percaya bahwa pengarang Kitab Suci masih hidup, berkarya, dan berbicara sampai sekarang. ${ }^{53}$ Ini bukan berarti penulis manusia teks masih hidup sampai sekarang, bukan pula berarti kanon masih terbuka dan dapat sewaktu-waktu ditambahkan, melainkan merujuk kepada Allah sebagai penulis firman yang masih dan terus bekerja sampai sekarang di dalam hati dan kehidupan umat-Nya sehingga firman yang ditulis di masa lampau itu masih berkuasa, berguna, memiliki arti dan relevan untuk menuntun kehidupan umat masa kini dengan segala kompleksitas pergumulannya. Sebagaimana karya penyelamatan Allah yang memang genap di dalam salib Yesus Kristus tetapi masih berlangsung hingga sekarang, demikian pula Kitab Suci dipandang sebagai tindakan komunikasi ilahi yang terus

\footnotetext{
${ }^{52}$ Meskipun dikatakan ekstrem, pandangan ini mempunyai kontribusi positifnya sendiri, khususnya dalam intensinya untuk menemukan makna objektif dari suatu teks di dalam teks itu sendiri dan meniadakan kemungkinan penyelewengan atau pergeseran makna oleh penulis atau komunitas tradisinya, dengan menerapkan serangkaian analisis pada bentuk dan struktur teks tersebut (lih. Hariyono Wongsohadi, "Tinjauan Kritis terhadap Hermeneutika Teks Gadamer dari Perspektif Hermeneutika Kaum Injili," (skripsi, STT SAAT, 2014), 3-4; Stanley E. Porter dan Jason C. Robinson, Hermeneutics: An Introduction to Interpretive Theory [Grand Rapids: Eerdmans, 2011], 154-189). 109.

${ }^{53}$ Bowald, "The Character," 172; Sutanto, "Reformed,"
}

berlangsung hingga sekarang. ${ }^{54}$ Mengenai hal ini, Watson berkomentar, "Though grounded in the past, the divine self-communication continues. The written Word is in no sense a substitute for a speaking God; rather, it is the place and the means of God's continued speaking." 55 Kitab Suci bukan semata-mata tempat atau situs untuk menemukan perkataan Allah, melainkan itu adalah bentuk kata-kata Allah yang sedang dan terus-menerus disuarakan hingga kini.

Keyakinan mengenai komunikasi ilahi yang masih terus berlangsung di dalam teks Kitab Suci akan menjadi semakin kokoh bila dipandang dalam bingkai karya penyelamatan Trinitas. Vanhoozer mengungkapkan bahwa natur dan fungsi Alkitab belum terengkuh sepenuhnya jika Alkitab belum dipandang sebagai sebuah elemen di dalam ekonomi penyelamatan Trinitas. ${ }^{56}$ Artinya, pemberian dan penafsiran Kitab Suci merupakan cara Allah untuk menyatakan diri-Nya agar manusia dapat mengenal-Nya dan beroleh keselamatan. ${ }^{57}$ Komposisi, kanonisasi, resepsi, bahkan interpretasi teks adalah bagian intrinsik di dalam garis sejarah penyelamatan Allah. ${ }^{58}$ Dengan demikian, tindakan menafsir sejatinya adalah partisipasi manusia di dalam drama

${ }^{54}$ Francis Watson, "Hermeneutics and the Doctrine of Scripture: Why They Need Each Other," IJST 12, no. 2 (April 2010): 124; bdk. Stephen E. Fowl, Theological Interpretation of Scripture, Cascade Companions (Eugene: Cascade, 2009), 6-7.

${ }^{55}$ Watson, "Hermeneutics," 127.

${ }^{56}$ Vanhoozer, "Ten Theses," 3. Penomoran halaman berbeda dengan data jurnal yang dijadikan referensi (lih. catatan kaki nomor 41) karena teks yang dirujuk ini merupakan ketikan asli berjumlah sepuluh halaman yang dikirimkan penulis melalui surel.

${ }^{57}$ Craig G. Bartholomew, Introducing Biblical Hermeneutics: A Comprehensive Framework for Hearing God in Scripture (Grand Rapids: Baker Academic, 2015), 5.

\footnotetext{
${ }^{58}$ Vanhoozer, "Ten Theses," 5; Bowald, "The Character," 181. Ini juga selaras dengan tesis pertama dan kedua Davis dan Hays, yaitu "Kitab Suci dengan penuh kebenaran menuturkan cerita perbuatan Allah dalam mencipta, menghakimi, dan menyelamatkan dunia" (The Art, 1).
} 
penebusan ilahi yang sudah, sedang, dan terus berlangsung di dalam dunia. ${ }^{59}$

Implikasinya, pertama, tindakan hermeneutis dapat dipandang sebagai sebuah dialog antara partisipan sejarah Allah dari masa lalu dengan masa kini, yaitu pembaca pertama teks, penerima teks dalam berbagai bentuk, sampai pembaca kontemporer. ${ }^{60}$ Maka, studi historis, literaris, leksiografis, dan narasi sejarah penafsiran di dalam tradisi yang berbeda-beda merupakan sebuah keniscayaan bagi pembaca kontemporer. Meskipun mungkin tidak semua langkah diterapkan, atau diterapkan dalam urutan yang berlainan, pembaca masa kini perlu membangun sebuah kesadaran bahwa teks tidak diterima di dalam ruang vakum, melainkan secara sinambung dari penulis, penerima pertama, serta gereja Kristen sepanjang zaman.

Kedua, tugas hermeneutika tidak hanya berhenti pada menanyakan maksud penulis bagi pembaca pertama, melainkan juga menanyakan maksud Allah di dalam teks kepada pembaca hari ini. Sutanto menegaskan, "the primary locus of meaning is thus in the context of the divine author and his intentions for the reader, instead of that of the mind of the historical author and his context." 61 Aplikasi pesan teks, yang sering dianggap sebagai tahapan homiletis, kini justru harus dimulai dan tidak dapat dipisahkan dari tahapan hermeneutis. Konteks pembaca yang kerap dihindari guna objektivitas penafsiran, oleh TIS tidak bisa tidak diperhitungkan mengingat pesan yang sedang dan akan terus-menerus disampaikan Allah. Ini juga berarti bahwa setiap pembaca Kitab Suci diundang untuk terus-menerus memperbarui pembacaan dan memperdalam pengertiannya terhadap teks, sampai kepada

${ }^{59}$ Matthew Levering, Participatory Biblical Exegesis: $A$ Theology of Biblical Interpretation (Notre Dame: University of Notre Dame, 2008), 1, 5; Billings, The Word of God, 200202; Bowald, "The Character," 182; Sutanto, "Reformed," 109.

${ }^{60}$ Levering, Participatory, 63.

${ }^{61}$ Sutanto, "Reformed," 109. hari Kristus Yesus ketika makna yang sempurna dan sejati itu dinyatakan. ${ }^{62}$

Kesatuan Narasi Perjanjian Lama dan

Perjanjian Baru di dalam Yesus Kristus

TIS tidak membaca setiap buku atau kelompok buku di dalam Kitab Suci secara mandiri dan terpisah-pisah satu sama lain. TIS juga tidak berfokus untuk menyelidiki teologi penulis kitab yang berbeda-beda tentang satu topik sebagaimana dikerjakan oleh teologi biblika. ${ }^{63}$ Alih-alih demikian, TIS mengembangkan pembacaan menyeluruh secara kanonis yang bertumpu pada kesinambungan kedua Perjanjian di dalam kehidupan dan karya salib Yesus Kristus. ${ }^{64}$

Davis dan Hays mengatakan bahwa penafsiran yang setia terhadap Kitab Suci menuntut sebuah perjumpaan dengan keseluruhan narasinya. ${ }^{65}$ Perjanjian Baru tidak dapat dipahami dengan tepat jika terpisah dari Perjanjian Lama, demikian pula Perjanjian Lama tidak dapat dipahami dengan tepat jika terpisah dari Perjanjian Baru. ${ }^{66}$ Menurut Billings, tanpa kanon yang mengikat secara inheren, buku-buku di dalam Kitab Suci hanya akan menjadi teks yang terpisah-pisah, tidak dapat disatukan, dan justru menjadi ragam suara yang berkontradiksi satu dengan lainnya dan tidak memberi kesaksian terhadap apa pun juga.$^{67}$

Implikasi dari keyakinan ini adalah pembacaan teks yang kanonik dan kristosentrik, dengan persepsi bahwa Yesus Kristus menjadi "batu penjuru" di dalam teks yang menyatukan seluruh diversitas. ${ }^{68}$ Ini menghidupkan

${ }^{62}$ Davis dan Hays, The Art, 5.

${ }^{63}$ Fowl, Engaging Scripture, 18-19.

${ }^{64}$ Sutanto, "Reformed," 110; Christopher Seitz, The Character of Christian Scripture, Studies in Theological Interpretation (Grand Rapids: Baker Academic, 2011), 43; Kevin J. Vanhoozer, "Theological Commentary,” 5.

${ }^{65}$ Davis dan Hays, The Art, 2.

${ }^{66}$ Vanhoozer, "Ten Theses," 5; Volf, Captive, 24.

${ }^{67}$ Billings, The Word of God, 33.

${ }^{68}$ Ongkowidjojo, "Theological Interpretation," 42. 
kembali cara pembacaan yang dilakukan oleh penafsir-penafsir patristik seperti Origen dan Ireaneus, yang mempelajari semua detail di dalam teks tetapi memandangnya dengan lensa kesinambungan dan similaritas penggenapannya di dalam Yesus Kristus. Pembacaan seperti ini memungkinkan satu teks ditafsir di dalam terang teks lainnya. Pada taraf tertentu, pembacaan seperti ini juga akan mengarah kepada-dan tidak dapat dilepaskan daripembacaan spiritual karena seluruh konten di dalam Kitab Suci diterangi oleh motif Yesus Kristus. ${ }^{69}$ Selain itu, pembacaan teks Kitab Suci di dalam bingkai narasi seperti ini juga menjadi pintu bagi peletakan wawasan dunia Kristen karena pembaca masa kini akan dilatih melihat dan menempatkan dirinya di dalam jalan cerita Allah yang masih terus berlangsung di dalam dan bagi dunia.

\section{Keterlibatan Lensa dan Tradisi Teologis di dalam Pembacaan}

Lensa atau tradisi teologis penafsir, yang oleh ceramah Gabler dan keilmuan modern dianggap sebagai "kutuk" yang mendistorsi penafsiran, justru oleh TIS dianggap sebagai "berkat" yang mencerahkan penafsiran. ${ }^{70}$ TIS justru ingin memberikan tempat yang seharusnya bagi teologi sebagai sesuatu yang mutlak perlu dan niscaya di dalam penafsiran. Tugas penafsiran di dalam kerangka berpikir TIS bukan hanya mencermati teks, tetapi juga lensa teologis yang dikenakan oleh penafsir.

Billings menyatakan, "My claim is that Christian should not seek to come to Scripture as a blank slate, but they should be both open and self-aware about the theological lens they bring to Scripture, the assumptions that make up our theological hermeneutic." 71 Pembaca yang cermat perlu menyadari bahwa proses menafsir itu bukan hanya berkaitan dengan teks, tetapi juga dengan kacamata yang digunakannya untuk membaca teks. Fowl juga mengatakan bahwa tindakan menafsir sesungguhnya

\footnotetext{
${ }^{69}$ Treier, Theological Interpretation, 45-50.

${ }^{70}$ Ibid., 39-40.

${ }^{71}$ Billings, The Word of God, 12.
}

adalah proses interaksi yang kompleks dan panjang antara pengakuan iman, praktik hidup, dan keprihatinan-keprihatinan kristiani. $^{72}$ Kedua pernyataan ini menunjukkan bahwa ada "sesuatu" yang dibawa ketika seseorang mendekati dan membaca teks.

Pada praksisnya, seseorang memang tidak pernah datang kepada Kitab Suci dengan sama sekali "polos" seperti tabularasa. Bapa-bapa Gereja dan penafsir pramodern yang lebih pagi pun sudah membaca teks dalam bingkai pengakuan iman.$^{73}$ Ada konsep, asumsi, atau prapengetahuan yang akan selalu berinteraksi dengan teks yang dibaca dan dimaknai. TIS memberi ruang lebih luas bagi prapengetahuan yang bersifat teologis, yang terbentuk misalnya melalui pembacaan sebelumnya, kehidupan bergereja, pengakuan iman, identitas, atau pengalaman pribadi sebagai orang percaya.

Perlu dipahami bahwa pembacaan dengan kesadaran dan keterlibatan lensa teologis bukan berarti mencocokkan kebenaran teks dengan keyakinan teologis yang sudah dimiliki. Melainkan, sebagaimana dikatakan Treier, kerangka doktrinal yang dibawa untuk mendekati teks justru akan menantang pembaca untuk menyadari asumsi-asumsi yang dimiliki selama ini dan "merevisinya" di dalam terang pemahaman gerejawi terhadap Kitab Suci. ${ }^{74}$ Dengan demikian, tindakan penafsiran menjadi sebuah proses yang berlangsung terus-menerus, dengan dipengaruhi dan memengaruhi lensa dan tradisi teologis di dalam refleksi iman. Makna yang diperoleh juga bukan berarti bisa berubah-ubah dalam setiap momen pembacaan, melainkan pembaca dapat memahami makna yang semakin lama semakin penuh dan mendalam, sampai kepada

\footnotetext{
${ }^{72}$ Fowl, Engaging Scripture, 8.
}

\footnotetext{
${ }^{73}$ Treier, Theological Interpretation, 46; Frances M. Young, Biblical Exegesis and the Formation of Christian Culture (Peabody: Hendrickson, 2002), 18; David C. Steinmetz, "The Superiority of Pre-Critical Exegesis," Theology Today 37 (1980): 30; Christopher A. Hall, Reading Scripture with the Church Fathers (Downers Grove: InterVarsity Academic, 1998), 13-15; Vanhoozer, "Theological Commentary," 5.

${ }^{74}$ Treier, Theological Interpretation, 77.
} 
pemahaman yang sempurna ketika pembaca bertemu dengan Kristus muka dengan muka.

\section{Pembacaan dalam Konteks Eklesial}

Penafsiran sebagai Kegiatan Bersama dalam Komunitas Umat Beriman

Pada Reformasi Protestan 1517, Luther menggaungkan keterbukaan akses seluas-luasnya terhadap pembacaan Kitab Suci termasuk bagi kaum awam yang pada masa itu umumnya tidak membaca teks. ${ }^{75}$ Ironinya, meskipun alat-alat tafsir modern semakin mudah diakses oleh semua kalangan, peluang untuk penafsiran yang individualis dan terbatas pada kaum terpelajar justru semakin besar. ${ }^{76}$ Salah satu aspek yang melatarbelakangi fenomena ini adalah ketegangan mengenai pemegang otoritas penafsiran di tengah diversitas kelompok Kristen setelah Reformasi Protestan yang secara bersamaan juga menghasilkan penafsiran yang jamak. ${ }^{77}$

Mewarisi tradisi penafsiran Kristen mulamula, TIS melibatkan kaum awam di dalam pembacaan dengan bersandarkan kepada tuntunan Roh Kudus yang memberi pengertian. ${ }^{78}$ Kaum awam atau orang-orang yang tidak mengenyam pendidikan Alkitab pun terhitung ke dalam bagian "imamat yang rajani" (1Ptr. 2:9) sehingga mungkin dan dapat untuk membaca dan menafsir teks. Dalam perspektif misi dan kesaksian gereja di tengah dunia, Kitab Suci juga dianggap sebagai "teks publik" yang tidak eksklusif bagi kalangan tertentu, tetapi dapat diakses oleh semua orang. ${ }^{79}$

${ }^{75}$ Alister E. McGrath, "Reclaiming Our Roots and Vision: Scripture and the Stability of the Christian Church," dalam Reclaiming the Bible, 69; Iain Provan, The Reformation and the Right Reading of Scripture (Waco: Baylor University Press, 2017), 3-8.

${ }^{76}$ Treier, Theological Interpretation, 79.

${ }^{77}$ Kevin J. Vanhoozer, Biblical Authority after Babel: Retrieving the Solas in the Spirit of Mere Protestant Christianity (Grand Rapids: Brazos, 2016), 16-17.

${ }^{78}$ Treier, Theological Interpretation, 79-80.

${ }^{79}$ Angus Paddison, “Theological Interpretation and the Bible as Public Text," JTI 8, no. 2 (2014): 177, 180, 182-183; bdk. Davis dan Hays, The Art, 4-5. Davis dan Hays beranggapan bahwa teks perlu dibaca dalam dialog dengan
Bahkan, spektrum pemikiran yang tidak terlalu mementingkan doktrin gereja di dalam penafsiran teks, beranggapan bahwa Kitab Suci terbuka dan dapat diterima oleh semua kalangan tanpa mementingkan keyakinan religius atau nilai-nilai pribadinya. ${ }^{80}$ Pandangan yang terakhir agaknya terlalu ekstrem karena justru dapat menjadi sama dengan ekses pandangan naturalisme modern yang membiarkan teks dibaca tanpa keyakinan religius bahkan menjadi sama seperti buku biasa. Jalan tengah yang mungkin dapat diambil berkenaan dengan keyakinan ini adalah bahwa Kitab Suci adalah teks religius yang memang dapat dibaca oleh semua orang, tetapi dalam hal ini gereja dipanggil untuk menjelaskan teks kepada dunia. ${ }^{81}$

Namun, pandangan mengenai keterbukaan akses Kitab Suci bagi semua orang ini juga tidak jauh dari ekses dan perdebatan. Pertama, adanya semacam "ketakutan" umum bahwa kaum awam dapat membaca teks dengan tidak tepat, salah menafsirkan, bahkan berpotensi jatuh kepada kesesatan. Kedua, karena semua orang bisa membaca teks, sangat mungkin timbul "keegoisan interpretatif" yang mengunggulkan penafsirannya sendiri dan memandang rendah atau salah penafsiran-penafsiran lain, sebagaimana dikatakan Vanhoozer:

Here, in a nutshell, is the Protestant dilemma: sola scriptura, coupled with the priesthood of all believers, seems to make each individual the final authority, and yet various Protestant individuals, each guided and illumined by

komunitas lain di luar gereja karena dari komunitas lain pun umat beriman dapat mengambil pelajaran.

${ }^{80}$ Bradley Pace, "Public Reason and Public Theology: How the Church Should Interfere," Anglican Theological Review 91 (2009): 274.

${ }^{81}$ Kevin J. Vanhoozer, The Drama of Doctrine, 118; bdk. David Yeago, "The Bible," dalam Knowing the Triune God, ed. James J. Buckley dan David S. Yeago (Grand Rapids: Eerdmans, 2001), 58. Vanhoozer memandang Filipus sebagai simbol dari gereja yang menafsirkan teks bagi orang-orang yang tidak mengerti jika tidak ada yang menjelaskan (Kis. 8:30-31). Dalam hal ini, gereja mempunyai pemahaman yang lebih daripada orang-orang yang tidak percaya, yaitu pemahaman akan kebangkitan Kristus yang menjadi dasar atau tumpuan bagi penafsiran teks. 
the Holy Spirit, disagree with one another. . . . The misleading picture of the priesthood of all believers as granting every individual the right to start a church fits hand in glove with what we may call interpretive egoism. . . . Extreme interpretive egoism is the view that privileges my interpretations simply because they are mine. ${ }^{82}$

Kritik yang pertama agaknya tidak terlalu banyak dibicarakan dalam diskusi TIS karena ada perbedaan perspektif tentang kebenaran makna. Kewaspadaan akan kesalahan tafsir atau kesesatan makna muncul dari pandangan yang mengasumsikan hanya ada satu makna yang tepat dan presisi, sementara TIS menerima ragam makna selama masih diikat dalam motif Yesus Kristus dan dibingkai dalam pengakuan iman. ${ }^{83}$

Kritik yang kedua mengenai keegoisan interpretatif dijawab Vanhoozer dengan mengingatkan bahwa "keimaman yang rajani" dari semua orang percaya itu berlangsung di dalam "tubuh" yang dikepalai oleh Yesus Kristus sebagai Imam Besar Agung. ${ }^{84}$ Vanhoozer mengatakan, "The Reformers emphasized the priesthood of all believers not as isolated but as gathered individuals, baptized members of a local body anointed with the Holy Spirit." ${ }^{85}$ Implikasinya, setiap orang di dalam tubuh Kristus memiliki kesempatan, kebebasan, dan tanggung jawab yang setara untuk melayankan firman dan karitas, tetapi tidak untuk menetapkan nilai benar atau salah untuk pelayanan anggota tubuh yang lain. ${ }^{86}$

Penafsiran di dalam konteks komunitas umat beriman tidak hanya memungkinkan semua orang melakukan pembacaan dan pelayanan firman, tetapi juga mengimplikasikan keniscayaan sejarah penafsiran. Sebagai pembaca masa kini, menafsir artinya melibatkan diri

\footnotetext{
${ }^{82}$ Vanhoozer, Biblical Authority, 19-20.

${ }^{83}$ Davis dan Hays, The Art, 2-3.

${ }^{84}$ Vanhoozer, Biblical Authority, 148, 157-15.

${ }^{85}$ Ibid., bdk. Robert McAfee Brown, The Spirit of Protestantism (Oxford: Oxford University Press, 1965), 97.

${ }^{86}$ Vanhoozer, Biblical Authority, 158.
}

di dalam konteks komunitas penafsir yang berdiri dan berkarya sepanjang zaman untuk menemukan pesan Allah bagi dunia. ${ }^{87}$ Implikasinya, penafsiran yang murni mandiri adalah sebuah kemustahilan atau justru menjadi sebuah keterlepasan diri dari komunitas penafsir yang beriman.

\section{Gereja sebagai Konteks Utama Penafsiran}

Berkaitan dengan konsep kebebasan penafsiran individu dalam konteks komunal, TIS memandang gereja sebagai konteks utama dan terbaik untuk dibangun dan berlangsungnya penafsiran. ${ }^{88} \mathrm{Hal}$ ini disebabkan oleh beberapa alasan. Pertama, gereja adalah tempat terbaik untuk tergenapinya tujuan komunikasi ilahi di dalam Kitab Suci, yaitu membentuk persekutuan antara Allah dengan umat dan sesama umat. ${ }^{89}$ Kedua, gereja itu sendiri memiliki identitas sebagai pengantin Kristus yang kepadanya Kristus memperdengarkan isi hati dan kehendak-Nya. ${ }^{90}$ Ketiga, pembentukan kanon itu sendiri dipengaruhi oleh partisipasi aktif gereja, sebagaimana dikatakan Childs:

These writings did not fall unmediated from heaven. Canon lays stress on the process of receiving and transmitting the treasured oracles of God. Moreover, this process of reception was not that of the recipients serving a passive role as an inert conduit, but as living and active tradents who both selected, formed, and ordered the Scriptures toward

\footnotetext{
${ }^{87}$ Komunitas penafsir yang dimaksud kebanyakan berasal dari era pramodern ketika pembacaan teks berlangsung dalam konteks gerejawi dan bertujuan untuk mendengar suara Allah bagi umat (lih. mis. Fowl, Theological Interpretation, 54-54; Billings, The Word of God, 151-155).

${ }^{88}$ Vanhoozer, "Ten Theses," 7; Robby Holt dan Aubrey Spears, "The Ecclesia as Primary Context for the Reception of the Bible," dalam Manifesto, 72-73.

${ }^{89}$ Vanhoozer, "Ten Theses," 7; Elizabeth Achtemeier, "The Canon as the Voice of the Living God," dalam Reclaiming the Bible, 119.

${ }^{90}$ Holt dan Spears, "The Ecclesia," 72-73; Sutanto, "Reformed," 110; Richard Swinburne, Revelation: From Metaphor to Analogy, ed. ke-2 (New York: Oxford University Press, 2007), 255.
} 
the goal of engendering faith and instructing every successive generation in righteousness. ${ }^{91}$

Dengan kata lain, dapat dikatakan bahwa eksistensi teks Kitab Suci dan eksistensi gereja Kristen saling memengaruhi dan mutlak tidak dapat dipisahkan.

TIS berkeyakinan bahwa teks Kitab Suci diberikan Allah pertama-tama untuk gereja, bukan kalangan akademis. Pembacaan Kitab Suci sebenarnya dimaksudkan untuk terjadi dalam mode "mendengar suara Allah," bukan semata-mata menyelidiki arti kata, data historis, filsafat, atau pandangan teologi penulis. ${ }^{92}$ TIS ingin menghidupkan kembali praktik-praktik hermeneutika teologis yang dianggap telah dan akan terus berlangsung di dalam kehidupan bergereja, misalnya dalam bentuk liturgi, devosi, katekisasi, dan homili. ${ }^{93}$ Dengan keyakinan akan karya dan pimpinan Roh Kudus, orang-orang kudus di dalam gereja dapat saling mengajar, mengoreksi, dan menjadi saksi untuk penafsiran dan penerapan Kitab Suci di dalam kehidupan..$^{94}$ Di sisi lain, perjalanan terus-menerus untuk mencari dan memahami suara Allah ini membuat gereja tidak bisa memandang diri sebagai standar final penafsiran. ${ }^{95}$

Dengan demikian, penafsiran akademis-kritis tidak dianggap lebih rendah atau tidak penting dibanding penafsiran praktis di dalam kehidupan gereja. Penafsiran dengan alat-alat bantu kritis tetap diperlukan dengan mempertimbangkan dua hal. Pertama, penafsir perlu menyadari bahwa ia merupakan bagian

${ }^{91}$ Brevard S. Childs, "On Reclaiming the Bible for Christian Theology," dalam Reclaiming the Bible, 9.

${ }^{92}$ Holt dan Spears, "The Ecclesia," 82-83; Markus Bockmuehl, Seeing the Word: Refocusing the New Testament Studies, Studies in Theological Interpretation (Grand Rapids: Baker Academic, 2006), 92.

${ }^{93}$ Jenson, "Hermeneutics and the Life of the Church," 90-92; Ongkowidjojo, "Theological Interpretation," 47-48; Watson, Text, Church, and the World, 5; Volf, Captive, 34.

${ }^{94}$ Treier, Theological Interpretation, 89; Billings, The Word of God, 134.

${ }^{95}$ Ongkowidjojo, "Theological Interpretation," 48-49; Billings, The Word of God, 134. dari tubuh Kristus yang Am dan sama sekali bukan sarjana terisolasi yang hanya meneliti teks untuk ilmu pengetahuan atau kuriositas pribadi. ${ }^{96}$ Kedua, segala penafsiran atau teologi yang dihasilkan harus kembali ditujukan untuk melayani dan membangun tubuh Kristus yang Am. ${ }^{97}$

\section{Transformasi Hidup Umat sebagai Tujuan Akhir Penafsiran}

Pendekatan TIS beranggapan bahwa tugas penafsiran belum selesai jika belum ada dampak nyata di dalam kehidupan umat. ${ }^{98}$ Penafsiran yang hanya berhenti pada pemahaman saja dianggap tidak cukup atau bahkan gagal. Aplikasi pesan teks bagi pembaca masa kini yang umumnya ditempatkan pada tahapan homiletis, ${ }^{99}$ kini menjadi bagian yang inheren pada tahapan hermeneutis. Pertanyaan utama di dalam tugas hermeneutika bukan lagi "what it meant" tetapi juga "what it means," atau dengan kata lain, pesan yang ingin disampaikan penulis teks, yaitu Allah sendiri, kepada pembaca masa kini dengan pergumulannya masing-masing. ${ }^{100}$

${ }^{96}$ Bdk. Richard Muller dan John L. Thompson, "The Significance of Precritical Exegesis: Retrospect and Prospect," dalam Biblical Interpretation in the Era of the Reformation: Essays Presented to David C. Steinmetz in Honor of His Sixtieth Birthday, ed. Richard Muller dan John L. Thompson (Grand Rapids: Eerdmans, 1996), 341.

${ }^{97}$ Treier, Theological Interpretation, 188; Kevin J. Vanhoozer, "In the Evangelical Mood: The Purpose of Pastor-Theologian," dalam Pastor as Public Theologians: Reclaiming a Lost Vision (Grand Rapids: Baker Academic, 2015), 112-113.

\footnotetext{
${ }^{98}$ Ongkowidjojo, “Theological Interpretation," 49; Vanhoozer, "Theological Commentary," 5.

${ }^{99}$ Lih. mis. Grant R. Osborne, The Hermeneutical Spiral: A Comprehensive Introduction to Biblical Interpretation, ed. rev (Downers Grove: InterVarsity Academic, 2006), 2425, 29-30; William W. Klein, Craig L. Blomberg dan Robert L. Hubbard, Jr., Introduction to Biblical Interpretation, ed. rev (Nashville: Thomas Nelson, 2004), 3-5; 18-19; Andreas Köstenberger dan Richard D. Patterson, Invitation to Biblical Interpretation: Exploring the Hermeneutical Triad of History, Literature, and Theology, Invitation to Theological Studies Series (Grand Rapids: Kregel, 2011), 790-795; Sidney Greidanus, The Modern Preacher and the Ancient Text: Interpreting and Preaching Biblical Literature (Grand Rapids; Leicester: Eerdmans; InterVarsity, 2003), 10-16.
}

${ }^{100}$ Volf, Captive, 25-26. 
Penekanan kepada aplikasi ini timbul dari keyakinan bahwa tujuan utama membaca Kitab Suci adalah untuk membiarkan Allah menjumpai kemanusiaan yang berdosa dan memberikan panduan, penghiburan, teguran, dan perubahan menuju keserupaan dengan Kristus bagi pelayanan kepada dunia. ${ }^{101}$ Transformasi hidup yang diharapkan terjadi juga bukan semata-mata penambahan informasi, melainkan perubahan menyeluruh bagi keutuhan pribadi dan totalitas gereja, meliputi dimensi-dimensi kognitif, emosional, sosial, spasial, dan psikologis. ${ }^{102}$

Postur pembacaan yang sesuai dengan keyakinan ini adalah postur yang atentif dan penuh respek untuk mendengar suara Allah, sebagaimana doa Samuel kecil, "Berbicaralah, sebab hamba-Mu ini mendengar" (1Sam. 3:10). ${ }^{103}$ Sikap mendengar ini ditandai dengan keheningan pada kedalaman diri demi menemukan suara Allah sendiri. ${ }^{104}$ Menariknya, Dietrich Bonhoeffer mengomentari hal ini:

Even in its acts of construing and interpreting, in bringing a communicative interest to bear upon the text, Christian reading act is a kind of surrender. Above all, faithful reading is an aspect of mortificatio sui, a repudiation of the desire to assemble all realities, including texts, including even the revelation of God, around the steady centre of my will. ${ }^{105}$

Dengan kata lain, dapat disimpulkan bahwa pembacaan teks yang dimotori oleh kerinduan untuk mendengar dan menaati perkataan Allah yang transformatif itu identik dengan

${ }^{101}$ Heath A. Thomas, "The Telos (Goal) of Theological Interpretation," dalam Manifesto, 197-198; Jenson, "Hermeneutics and the Life of the Church," 91.

${ }^{102}$ Thomas, "The Telos," 205; George H. Guthrie, Read the Bible for Life: Your Guide to Understanding and Living God's Word (Nashville: Broadman \& Holman, 2011), 5.

${ }^{103}$ Bartholomew, Introducing Biblical Hermeneutics, 18.

${ }^{104}$ Ibid., 20; bdk. G.C. Fiumara, The Other Side of Language: A Philosophy of Listening (London: Routledge, 1995), 115.

${ }^{105}$ Dietrich Bonhoeffer, Life Together; Prayerbook of the Bible, Dietrich Bonhoeffer Works 5 (Minneapolis: Fortress, 1996), 99. sikap hening, rendah hati, dan terbuka dalam menanti-nantikan Allah. Lebih lanjut, jika perkataan Allah itu kemudian menjumpai atau mengonfrontasi bagian diri kita yang tidak berkenan di hadapan-Nya, kita perlu merelakan diri kita untuk dikoreksi dan dipulihkan kembali sampai kita merengkuh keserupaan yang lebih penuh dan sempurna dengan Sang Firman itu sendiri.

\section{KESIMPULAN: PENDEKATAN TIS DAN PENGGUNAANNYA}

Melalui pemaparan di atas, terlihat bahwa sejatinya pendekatan TIS adalah sebuah pendekatan pembacaan Kitab Suci yang terjadi di dalam dua konteks sekaligus, yaitu konteks teologis dan konteks eklesial. Keyakinan ini berarti Kitab Suci dibaca dengan kesadaran penuh akan naturnya sebagai tulisan yang bersifat teologis-spiritual dan perlu dibaca selaras dengan natur tersebut. Pembacaan yang setia terhadap natur teks yang demikian agaknya paling baik terjadi di dalam, oleh, dan bagi komunitas umat percaya dengan pimpinan Roh Kudus. Sampai di sini, kita dapat melihat bahwa keyakinan dan praktik TIS sebenarnya bukan sesuatu yang sama sekali baru, melainkan sudah dan akan terus dilakukan di dalam gereja Tuhan di sepanjang abad dan tempat. Upaya yang dilakukan tokohtokoh dan tulisan-tulisan yang mendiskusikan pendekatan TIS tidak lain adalah "menamai" sesuatu yang memang sudah sangat lazim dijumpai dalam praktik kehidupan beriman dan tradisi Kristen hingga hari ini.

Ada beberapa implikasi praktis yang dapat dipikirkan lebih lanjut atau diterapkan di dalam gereja Kristen untuk mengejawantahkan pendekatan TIS ini di dalam bahasa yang lebih sederhana dan relevan. Pertama, para rohaniwan dapat memperluas cakrawala hermeneutis dan homiletisnya, khususnya di dalam berkhotbah, untuk tidak hanya menggali dan mengkhotbahkan makna satu bagian tertentu di dalam Kitab Suci semata, tetapi mengaitkannya dengan keseluruhan narasi penyelamatan Trinitas di dalam Yesus Kristus. Kedua, gereja dapat memberlakukan 
kembali pembacaan publik terhadap Kitab Suci di dalam ibadah-ibadah korporat karena pembacaan dari bagian-bagian teks yang berbeda tetapi dirangkai secara leksionaris justru akan mengembangkan kerangka narasi Alkitab yang utuh di dalam hati dan pikiran umat. Ketiga, jika selama ini kegiatan pembacaan dan pembelajaran Alkitab lebih menekankan fungsi pengajar yang memaparkan teks kepada umat, agaknya kini penekanannya dapat dialihkan kepada partisipasi umat sebagai orang-orang kudus yang bersamasama menggumulkan dan membicarakan Kitab Suci dalam pergulatan iman dan keseharian. Kiranya Allah Trinitas di dalam kuasa Roh Kudus membentuk gereja-Nya menjadi pembaca teks yang saleh dan setia, dan pembacaan teks Kitab Suci yang saleh dan setia akan membentuk gereja menjadi mempelai yang semakin berkenan di hadapan Pengantin Kudus-Nya.

\section{DAFTAR KEPUSTAKAAN}

Achtemeier, Elizabeth. "The Canon as the Voice of the Living God." Dalam Reclaiming the Bible for the Church, diedit oleh Carl E. Brateen dan Robert W. Jenson, 119-130. Grand Rapids: Eerdmans, 1995.

Allison, Gregg R. "Theological Interpretation of Scripture: An Introduction and Preliminary Evaluation." SBJT 14, no. 2 (2010): 28-36.

Bartholomew, Craig G. Introducing Biblical Hermeneutics: A Comprehensive Framework for Hearing God in Scripture. Grand Rapids: Baker Academic, 2015.

Billings, J. Todd. The Word of God for the People of God: An Entryway to the Theological Interpretation of Scripture. Grand Rapids: Eerdmans, 2010.

Blomberg, Craig L. "The Historical Critical/Grammatical View." Dalam Biblical Hermeneutics: Five Views, diedit oleh Stanley E. Porter dan Beth M. Stovell, 2747. Downers Grove: Intervarsity, 2012.
Bockmuehl, Markus. Seeing the Word: Refocusing the New Testament Studies. Studies in Theological Interpretation. Grand Rapids: Baker Academic, 2006.

Bonhoeffer, Dietrich. Life Together; Prayerbook of the Bible. Dietrich Bonhoeffer Works 5. Minneapolis: Fortress, 1996.

Bowald, Mark Alan. "The Character of Theological Interpretation of Scripture." IJST 12, no. 2 (April 2010): 162-183.

Brown, Robert McAfee. The Spirit of Protestantism. Oxford: Oxford University Press, 1965.

Burnett, Richard E. Karl Barth's Theological Exegesis: The Hermeneutical Principles of the Römerbrief Period. Grand Rapids: Eerdmans, 2001.

Carson, D. A. "Theological Interpretation of Scripture: Yes... But..." Dalam Theological Commentary: Evangelical Perspectives, diedit oleh R. Michael Allen, 781-803. London: T\&T Clark, 2011.

Childs, Brevard S. "On Reclaiming the Bible for Christian Theology." Dalam Reclaiming the Bible for the Church, diedit oleh Carl E. Brateen dan Robert W. Jenson, 1-18. Grand Rapids: Eerdmans, 1995.

Cunningham, Mary Kathleen. "Karl Barth." Dalam Christian Theologies of Scripture, diedit oleh Justin S. Holcomb, 183-201. New York: New York University Press, 2006.

Davis, Ellen F., dan Richard B. Hays, ed. The Art of Reading Scripture. Grand Rapids: Eerdmans, 2004.

Fowl, Stephen E. Engaging Scripture: A Model for Theological Interpretation. Oxford: Blackwell, 1998.

- Theological Interpretation of Scripture. Cascade Companions. Eugene: Cascade, 2009.

Green, Joel B. "The (Re-)Turn to Theology." JTI 1, no. 1 (2007): 1-3. 
. "Scripture and Theology: Uniting the So Long Divided." Dalam Between Two Horizons: Spanning New Testament Studies and Systematic Theology, diedit oleh Joel B. Green dan Max Turner, 23-43. Grand Rapids: Eerdmans, 2000.

Seized by the Truth: Reading the Bible as Scripture. Nashville: Abingdon, 2007.

Greidanus, Sidney. The Modern Preacher and the Ancient Text: Interpreting and Preaching Biblical Literature. Grand Rapids: Eerdmans, 2003.

Guthrie, George H. Read the Bible for Life: Your Guide to Understanding and Living God's Word. Nashville: Broadman \& Holman, 2011.

Hall, Christopher A. Reading Scripture with the Church Fathers. Downers Grove: Intervarsity Academic, 1998.

Holt, Robby, dan Aubrey Spears. "The Ecclesia as Primary Context for the Reception of the Bible." Dalam A Manifesto for Theological Interpretation, diedit oleh Craig G. Bartholomew dan Heath A. Thomas, 72-93. Grand Rapids: Baker Academic, 2015.

Jenson, Robert W. "Hermeneutics and the Life of the Church." Dalam Reclaiming the Bible for the Church, diedit oleh Carl E. Brateen dan Robert W. Jenson, 89-105. Grand Rapids: Eerdmans, 1995.

Jowett, Benjamin. "On the Interpretation of Scripture." Dalam Essays and Reviews. Ed. ke-7. London: Longman, 1861.

Kelsey, David. Eccentric Existence: A Theological Anthropology. Louisville: Westminster John Knox, 2009.

Klein, William W., Craig L. Blomberg, dan Robert L. Hubbard, Jr. Introduction to Biblical Interpretation. Edisi Revisi. Nashville: Thomas Nelson, 2004.

Köstenberger, Andreas, dan Richard D. Patterson. Invitation to Biblical Interpretation:
Exploring the Hermeneutical Triad of History, Literature, and Theology. Invitation to Theological Studies Series. Grand Rapids: Kregel, 2011.

Levering, Matthew. Participatory Biblical Exegesis: A Theology of Biblical Interpretation. Notre Dame: University of Notre Dame, 2008.

Louth, Andrew. Discerning the Mystery: An Essay on the Nature of Theology. Oxford: Oxford University Press, 1983.

McGrath, Alister E. "Reclaiming Our Roots and Vision: Scripture and the Stability of the Christian Church." Dalam Reclaiming the Bible for the Church, diedit oleh Carl E. Brateen dan Robert W. Jenson, 63-88. Grand Rapids: Eerdmans, 1995.

Moberly, R.W. L. "What Is Theological Interpretation of Scripture?." JTI 3, no. 2 (2009): 161-178.

Muller, Richard, dan John L. Thompson, "The Significance of Precritical Exegesis: Retrospect and Prospect." Dalam Biblical Interpretation in the Era of the Reformation: Essays Presented to David C. Steinmetz in Honor of His Sixtieth Birthday, diedit oleh Richard Muller dan John L. Thompson, 335-345. Grand Rapids: Eerdmans, 1996.

Ongkowidjojo, Hendry. "Theological Interpretation of Scripture: Suatu Pengantar." Jurnal Amanat Agung 9, no. 1 (Juni 2013): 35-55.

Osborne, Grant R. The Hermeneutical Spiral: A Comprehensive Introduction to Biblical Interpretation. Revised and Expanded. Downers Grove: Intervarsity, 2006.

Pace, Bradley. "Public Reason and Public Theology: How the Church Should Interfere." Anglican Theological Review 91 (2009): 273-292.

Paddison, Angus. "The History and Reemergence of Theological Interpretation." Dalam $A$ Manifesto for Theological Interpretation, diedit oleh Craig G. Bartholomew 
dan Heath A. Thomas, 27-47. Grand Rapids: Baker Academic, 2015.

"Theological Interpretation and the Bible as Public Text." JTI 8, no. 2 (2014): 175-192.

Pasquarello III, Michael. "Back to the Future: The Promise of Recent Theological Commentary." JTI 3, no. 2 (2009): 307-315.

Porter, Stanley E. "What Exactly Is Theological Interpretation of Scripture, and It Is Hermeneutically Robust Enough for the Task to Which It Has Been Appointed?." Dalam Horizons in Hermeneutics: A Festschrift in Honor of Anthony C. Thiselton, diedit oleh Stanley E. Porter dan Matthew R. Malcolm, 234-267. Grand Rapids: Eerdmans, 2013.

Provan, Iain. The Reformation and the Right Reading of Scripture. Waco: Baylor University Press, 2017.

Rae, Murray. "Theological Interpretation and Historical Criticism." Dalam A Manifesto for Theological Interpretation, diedit oleh Craig G. Bartholomew dan Heath A. Thomas, 94-109. Grand Rapids: Baker Academic, 2015.

Rowe, C. Kavin, dan Richard B. Hays, "What is a Theological Commentary?: A Book Symposium on Jaroslav Pelikan, Acts, Brazos Theological Commentary on the Bible (Grand Rapids: Brazos, 2005)." Pro Ecclesia 16, no. 1 (2007): 26-32

Saragih, Denni Boy. "Disruptive Presence: The Ontology, Theology andEthics of Reading the Bible as Scripture in Karl Barth's Theological Exegesis." Disertasi, University of Edinburgh, 2015.

Sarisky, Darren. "What is Theological Interpretation?." IJST 12, no. 2 (April 2010): 201-216.

Scobie, Charles H. H. The Ways of Our God: An Approach of Biblical Theology. Grand Rapids: Eerdmans, 2003.
Seitz, Christopher. The Character of Christian Scripture. Studies in Theological Interpretation. Grand Rapids: Baker Academic, 2011.

Spinks, D. Christopher. The Bible and the Crisis of Meaning: Debates on the Theological Interpretation of Scripture. London: T\&T Clark, 2007.

Steinmetz, David C. "The Superiority of Pre-Critical Exegesis." Theology Today 37 (1980): 27-38.

Sutanto, Nathaniel Gray. "Toward a Reformed Theological Interpretation of Scripture.” Jurnal Teologi Indonesia 1, no. 1 (2013): 103-116.

Swinburne, Richard. Revelation: From Metaphor to Analogy. Ed. ke-2. New York: Oxford University Press, 2007.

Thomas, Heath A. "The Telos (Goal) of Theological Interpretation." Dalam $A$ Manifesto for Theological Interpretation, diedit oleh Craig G. Bartholomew dan Heath A. Thomas, 27-47. Grand Rapids: Baker Academic, 2015.

Treier, Daniel J. Introducing Theological Interpretation of Scripture: Recovering a Christian Practice. Grand Rapids: Baker Academic, 2008.

"What is Theological Interpretation? An Ecclesiological Reduction." IJST 12, no. 2 (April 2010): 144-161.

Turner, Max, dan Joel B. Green. "New Testament Commentary and Systematic Theology: Strangers or Friends?.” Dalam Between Two Horizons: Spanning New Testament Studies and Systematic Theology, diedit oleh Joel B. Green dan Max Turner, 1-22. Grand Rapids: Eerdmans, 2000.

Vanhoozer, Kevin J. "Ascending the Mountain; Singing the Rock: Biblical Interpretation Earthed, Typed, and Transfigured." Modern Theology 28, no. 4 (Oktober 2012): 781-803. 
Biblical Authority after Babel: Retrieving the Solas in the Spirit of Mere Protestant Christianity. Grand Rapids: Brazos, 2016.

The Drama of Doctrine: A Canonical-Linguistic Approach to Christian Theology. Louisville: Westminster John Knox, 2005.

. "Exegesis I Know, and Theology I Know, But Who Are You?': Acts 19 and the Theological Interpretation of Scripture." Dalam Theological Theology: Essays in Honor of John B. Webster, diedit oleh R. David Nelson, Darren Sarisky dan Justin Stratis, 289-306. Bloomsbury: T\&T Clark, 2015.

First Theology: God, Scripture, and Hermeneutics. Downers Grove: Intervarsity, 2002.

"In the Evangelical Mood: The Purpose of Pastor-Theologian." Dalam Kevin J. Vanhoozer dan Owen J. Stratchan, The Pastor as Public Theologians: Reclaiming a Lost Vision, 103-131. Grand Rapids: Baker Academic, 2015.

"Introduction: What is Theological Interpretation of the Bible.?" Dalam Dictionary for the Theological Interpretation of the Bible, diedit oleh Kevin J. Vanhoozer, 19-25. Grand Rapids: Baker Academic, 2005.

Is There a Meaning in This Text?: The Bible, The Reader, and the Morality of Literary Knowledge. Grand Rapids: Zondervan, 1998.
-. "Theological Commentary and "the Voice from Heaven"' Exegesis, Ontology, and the Travail of Biblical Interpretation." Dalam On the Writing on the New Testament Commentary: Festschrift for Grant R. Osborne on the Occasion of His $70^{\text {th }}$ Birthday, diedit oleh Stanley E. Porter dan Eckhard J. Schnabel, 267-298. Leiden: Brill, 2012.

. "Ten Theses on the Theological Interpretation of Scripture." Modern Reformation 19, no. 4 (2010): 16-19.

Volf, Miroslav. Captive to the Word of God: Engaging the Scripture for Contemporary Theological Reflection. Grand Rapids: Eerdmans, 2010.

Watson, Francis. "Hermeneutics and the Doctrine of Scripture: Why They Need Each Other." IJST 12, no. 2 (April 2010): 118-143.

Text, Church, and World: Biblical Interpretation in Theological Perspective. Grand Rapids: Eerdmans, 1994.

Webster, John. "Editorial." IJST 12, no. 2 (April 2010): 116.

Yeago, David. “The Bible.” Dalam Knowing the Triune God, diedit oleh James J. Buckley dan David S. Yeago, 49-94. Grand Rapids: Eerdmans, 2001.

Young, Frances M. Biblical Exegesis and the Formation of Christian Culture. Peabody: Hendrickson, 2002. 